\title{
On Colonial Industries: the Remnants of Bygone Sugar Factories in Taiwan
}

\author{
Hui-Wen Lin
}

\begin{abstract}
Taiwan's sugar industry during Japanese rule had a great and lasting effect on society, the use of space, and the Taiwanese populace. In order to develop Taiwan's sugar industry and its own immigration policies during Taiwan's time as a Japanese colony (1895-1945), Japan first improved industrial technologies and business operations, slowly replacing traditional sugar production methods with machinery. Next, Japanese capitalists were encouraged to build new sugar refineries and introduce new technologies and strict policies into the sugar industry. During its peak of these efforts, 42 modern sugar factories were built throughout Taiwan. This study investigates a representative group of 10 new sugar refineries built during Taiwan's time as a Japanese colony and owned by four Japanese sugar companies. The factory interior and exterior environments were used to analyze the principles which influenced sugar factory construction and related background information, while the human environment and natural environment were used to analyze the colonial industrial space.
\end{abstract}

Index Terms - Colonial, industry, sugar factory, Taiwan.

\section{INTRODUCTION}

"If you can speak Chinese, please speak Chinese; if you cannot speak Chinese, please learn Chinese."

"Everyone is responsible for protecting the sugar cane."

"Protect the sugar cane, help Taiwan's economic development."

These are a few of the slogans related to the sugar industry that were posted at Annei Elementary School, an affiliate of Taiwan Sugar Corporation, during Japanese rule. From this we can see that during the Japanese occupation, sugar companies were important to the Taiwanese people. The sugar industry at the time was Japan's main focus in Taiwan and served as the basic prototype for Taiwan's industries; it was also the prime force behind the "economic miracle" that took place after the KMT government moved to Taiwan. As Tadao Yanaihara once put it, "The history of the sugar cane industry is colonial history" [1]. During their occupation of Taiwan, Japan developed the sugar industry, bringing Taiwan into the fold of an imperialist capitalist society. Taiwan went from using traditional sugar manufacturing methods to using new mechanized factories, making sugar production an important colonial industry that brought change to Taiwan's people, society, history, and environment.

Manuscript received June 10, 2014; revised August 10, 2014. This work was supported in part by the National Science Council Research Project Grant 99-2410-H-168-014-.

Hui-Wen Lin is with the Institute of Creative Industries, National Cheng Kung University, Taiwan (e-mail: hwlin@ mail.ncku.edu.tw).

\section{A. Taiwan's Sugar Industry Cultural History}

Sugar cane, which is purported to have originated near the Ganges river basin on the Indian peninsula, is used as the raw material to make granulated sugar. Granulated sugar was an important trade commodity as early as the Crusades in the Middle Ages. As there are no written records of the origins of sugar cane cultivation and sugar production in Taiwan, only unclear oral accounts are available. In the mid-fifteenth century, the wave of Han Chinese people who then immigrated to Taiwan began exploring sugar cane's potential [2]. As the climate, soil, and rainfall in southeastern coastal China, particularly in Zhangzhou and Quanzhou in Fujian Province, were especially suited for growing tea and sugar cane, these immigrants brought sugar cane seedlings and sugar manufacturing methods to Taiwan with them nearly four hundred years ago.

The West Indies were first called the "sugar islands" or "sugar colonies", and were where mercantilists in Western Europe first began using African slaves for planting sugar cane. Afterwards, East Indian colonies, such as Mauritius, India, and Java, became sugar colonies as well, mainly producing sugar cane crops to meet the increasing demand for granulated sugar as it became an everyday commodity for Europeans in the $17^{\text {th }}$ century. Following this trend, Holland, in search of a place to conduct trade with East Asia and Japan, twice occupied the island of Penghu, and then occupied Taiwan in August of 1642. After Holland took over Taiwan, the scattered edible sugar cane produced in Taiwan took its first steps to becoming an economic crop under Holland's mercantilist control. Regardless of Holland's intentions in occupying Taiwan, their focus on commercial trade quickly made Taiwan's economy an export-driven commercial economy. The Dutch East India Company used Taiwanese labour to concentrate cultivation, increase production, and enter the international sugar market. Taiwanese sugar was mainly sold to Japan to open the doors to trade.

When Koxinga came to Taiwan in 1661, Taiwan's sugar industry policies were still much the same as under Dutch rule, and although Koxinga's exiled Chinese regime brought along many Han Chinese immigrants and China's traditional political system, his anti-Qing stance had much the same effect as Holland had on Taiwan's sugar industry. The foreign trade benefits of Taiwan's sugar industry were mostly used to fund his political campaigns to resist the Qing dynasty. However, the majority of Han immigrants and soldiers who helped cultivate lands had a large impact on land development in Taiwan. The Han Chinese also took over the Taiwanese sugar industry from the Dutch, and after becoming the main power in Taiwan, places that produced sugar were referred to as tangbu. Business models for these tangbu were divided into niugua bu (sugar factories operated 
by 15-40 people and 15-30 oxen), niuben bu (small organizations that covered everything from growing sugar cane to making sugar; as members were few, sugar production could be commissioned or pressed sugar cane could be purchased), gongjia bu (joint stock sugar factories owned by 2-5 people), and toujia bu (factories invested in and established by a single capitalist) [2]. The place names in Taiwan which still contain this $b u$ today are the areas in which sugar was manufactured in the past. Koxinga's political power in Taiwan lasted little longer than two decades, and in 1684, Taiwan became part of the Qing dynasty. Its lands were developed even further, attracting large numbers of immigrants. England, the US, and France soon became part of Taiwan's sugar trade.

\section{THE SUGAR INDUSTRY DURING 50 YEARS OF JAPANESE RULE}

A new phase for Taiwan's sugar industry began when Japan took over control of Taiwan from the Qing dynasty in 1895. Under Japanese rule, Taiwan's sugar industry gradually quit using the traditional tangbu sugar refining process and introduced sugar refineries with new processes. After the first sugar refinery to incorporate a new production process and selective breeding was established in Kio-A-Thau, Taiwan's sugar industry increased production by tenfold in just ten years, becoming an economic miracle within the worldwide sugar industry. Due to Europe's inability to balance sugar tariffs and subsidies before and after World War I, the international price for Taiwanese sugar held an advantage. 1920 was a golden time for the sugar industry as international sugar prices rose threefold. In 1932, Taiwan's production reached 960,000 metric tons, becoming an important economic pillar for the Japanese empire; however, the policies adopted by colonial Japan exploited farmers to increase profits for sugar factories. Taiwanese sugarcane farmers soon began saying that "it was ludicrous that Japanese companies weighed their crops," showing the plight of Taiwanese farmers under Japanese rule [3].

Japanese commercial groups led by Mitsui \& Co. obtained much support and funding from the governor-general's office for Taiwan, going on to establish Japanese sugar companies and the Bank of Taiwan to serve as the financial centre for Taiwan's sugar industry. At the time, the rich Taiwanese elite received benefits from the Japanese empire and sugar stocks and were allowed to create sugar companies. Contributions to Taiwan followed the construction of the railroads, postal services, electric systems, and commercial industrialization (foundries, distilleries, etc.) created for the sugar industry. In 1895 , the Japanese enacted a policy which focused industry in Japan and agriculture in Taiwan; the goal of the colonial policy was to revitalize the industry, mainly by giving incentives to help the sugar industry become self-sufficient. In 1900, a number of Japanese sugar factories were built in Taiwan, as was a new sugar production plant in Kio-A-Thau, increasing production and lowering costs. This was the beginning of Taiwan's new type of sugar factories. Dr. Inazo Nitobe published recommendations for improving the sugar industry in 1901, in which he proposed a plan to revitalize the sugar industry and established a Sugar Bureau underneath the governor-general's office to enforce sugar policies [2]. Soon after sugar cane inspection depots were built, acts for improving sugar cane varieties and cultivation methods were passed, irrigation equipment was constructed, sugar cane fields were widened, sugar production methods were improved, and a harvest system for raw materials was enforced to ensure consistent materials and products at all sugar factories. Sugar export taxes were also removed to encourage exports. From 1905 to 1909, aside from the existing sugar companies in Taiwan, the Ensuiko, Xinxing, Meiji, Dongyang, Lin Ben Yuan, Xingao, Imperial, and Dai-Nippon sugar companies also established new plants. After several reformations, these wealthy sugar companies supported by the colonial government soon became leaders in Taiwan's sugar industry. In 1912, Taiwan had 26 new sugar refineries and 32 improved tangbu, and was capable of pressing 23,890 tons of sugar cane; however, behind the development of Taiwan's sugar industry was stable Japanese colonization.

Sugar prices rose in 1920, bringing unprecedented prosperity to Taiwan's sugar industry. The following year, however, Taiwan suffered terrible losses as prices dropped dramatically. In an attempt to recover over the next few years, Taiwan introduced a large stalk variety of sugar cane and improved cultivation systems. With hard work, a record high in production was reached in 1925, and in 1929, the sugar industry finally became self-sufficient. Sugar companies merged in 1930 to create four major Japanese companies: Nikko Sugar Co. Ltd. (15 refineries), Taiwan Sugar Co. Ltd. (12 refineries), Meiji Sugar Co. Ltd. (8 refineries), and Ensuiko Sugar Co. Ltd. (7 refineries) [4]. This streamlined the sugar industry, and along with planting better varieties and improving harvesting management, sugar production increased $13.59 \%$ the same year. In 1937 the Second Sino-Japanese War began, and two years later sugar began to be rationed as production fell due to three disastrous attacks. In 1941, Taiwan had 50 new sugar refineries, pressing 70,120 tons of sugar cane per day, the peak of Taiwan's sugar industry. Taiwan Sugar factory and other factories were later bombed by Allied forces before the Japanese surrendered unconditionally in 1945 , with 34 of the 42 sugar refineries in Taiwan being destroyed.

This study investigated ten of the sugar refineries owned by the four major Japanese sugar corporations during the Japanese occupation: 1. Taiwan Sugar Co. Ltd. (established in 1900), represented by A-hou sugar plant (Pintung sugar refinery), Kio-A-Thau sugar plant (Kio-Thau sugar refinery), Wanli sugar plant (Shanhua sugar refinery), Sankantensya sugar plant (Yongkang sugar refinery), and Cheluqian sugar plant (Rende sugar refinery). 2. Meiji Sugar Co. Ltd. (established in 1906), represented by Xiaolong plant (Jiali sugar refinery), Suantou plant (Suantou sugar refinery), and Zongye plant (Zongye sugar refinery). 3. Nikko Sugar Co. Ltd. (established in 1909), represented by Chiayi plant (Dalin sugar refinery). 4. Ensuiko Sugar Co. Ltd. (established in 1907), represented by Annei sugar plant (Annei sugar refinery).

\section{INTERIOR STRUCTURE OF SUGAR REFINERY}

The new factories introduced by Japan had a special 
significance for the colonial rule of Taiwan. The Japanese sugar companies and production factories represented more than just the industry, they also represented Japan's part in Taiwan's economy, society, and government. This special cultural significance is also evident in the spatial appearances of these factories. The structures of the sugar refineries and their surrounding spaces were built with the purpose of making sugar. In contrast, the structure of the interior space was more complex in that it had to accommodate long-term residence by the Japanese. Employee dorms and other facilities were also conceived at the very beginning of the plants' construction; therefore, the factory and the surrounding community were designed at the same time. In other words, the entire sugar refinery area was a comprehensive project. Conditions for the establishment of the new factories were based on supply, allocations, and production. Supply was governed mostly by raw materials and water; if the sugar refinery was positioned in the centre of the sugar cane fields, the sugar cane could be quickly sent to the factory for pressing. Places near water sources were considered for construction. Allocation was governed by transportation convenience. Bringing in raw materials and shipping finished product both required transportation; therefore, new factories were placed near railways or roads to reduce expenses. Otherwise, new roads needed to be built, such as the sugar railways. Production was regulated by constructing factories in areas with abundant labour forces [5].

The planning for sugar refineries during the Japanese occupation divided land use into three areas according to operational requirements: a factory area for sugar manufacturing, an office area for administrative activities, and a residential area for employee living. The office area was a buffer between the residential and factory areas. Aside from these three main areas, other facilities were also included, such as public facilities (hospitals, schools, and shrines), entertainment facilities (clubs, parks, gyms, and communal areas), and public bathhouses, to create a complete living area [6]. Transportation facilities (train stations), police stations, and post offices were also included. As Table I shows the arrangements of the 10 representative factories along with the spatial relationship within the entire facility. Explanations for the locale and overall planning of the facilities and relevant support within the factory are also included (see Table I).

TABLE I: SPATIAL ARRANGEMENT OF THE 10 SUGAR RFACTORIES

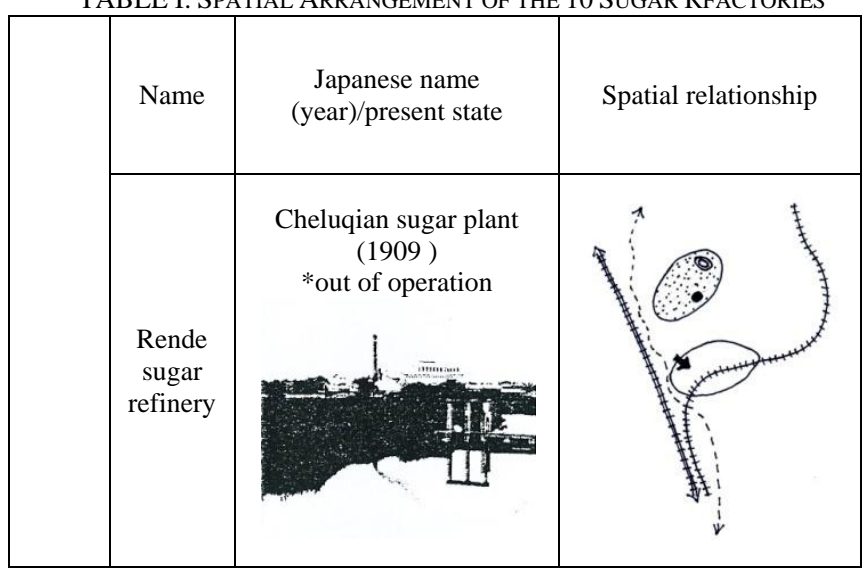

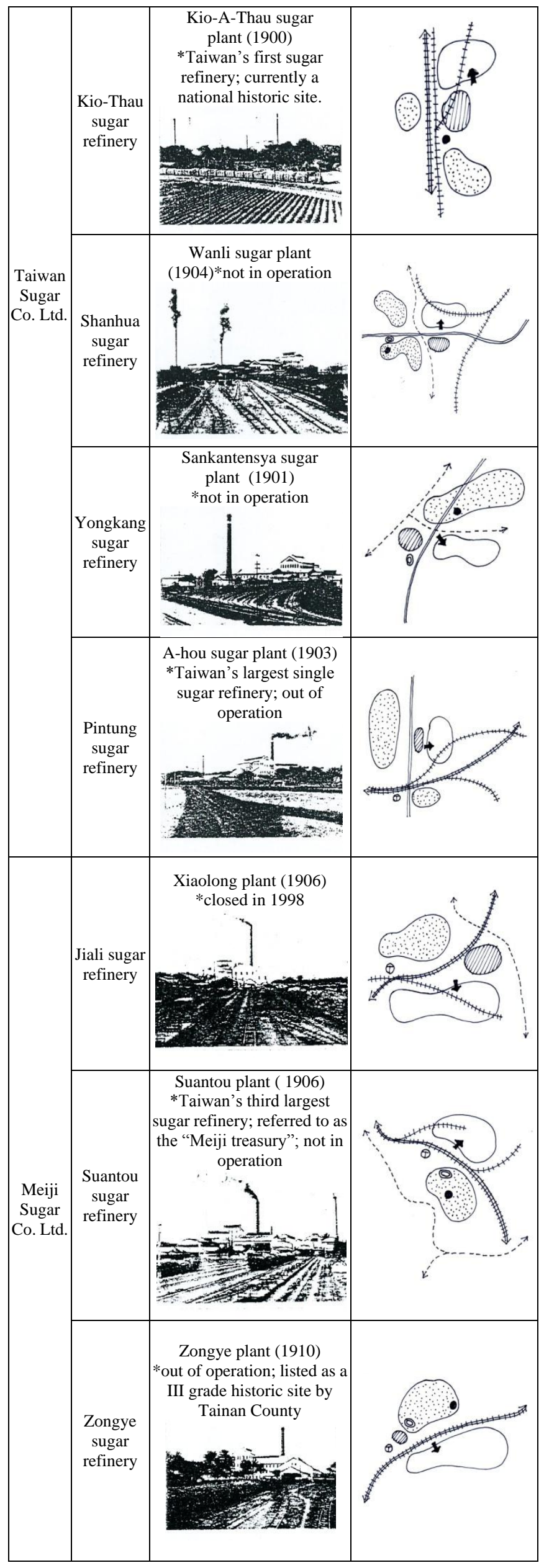



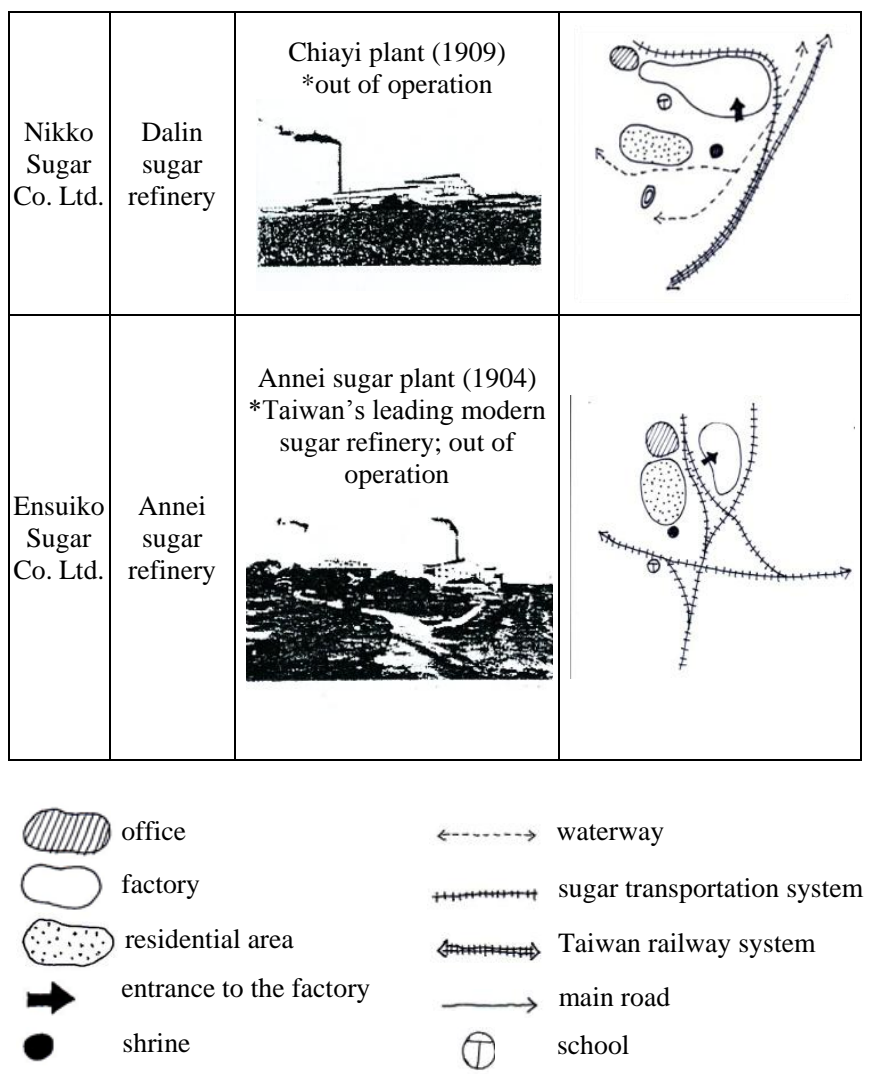

Below are descriptions of the areas included in the representative sugar refineries.

\section{A. Factory Area}

Sugar production facilities were influenced by the development of the railways, and their locations were decided by the supply of raw materials and nearby waterways. The majority of early sugar refineries were built in the southwest of Taiwan (south of Zhuoshui River). During the middle of the Japanese occupation, as the Regulations for the Prohibition of Sugar Refineries passed in 1905 stated that factories must provide space for raw materials and obtain permission from the governor-general's office before construction, and following the completion of the Guanying railway system in Guanxi, sugar refineries were more dispersed. The spaces in factory areas were divided into storage areas, sugar processing areas, and machinery maintenance areas which were connected by rail (see Fig. 1)

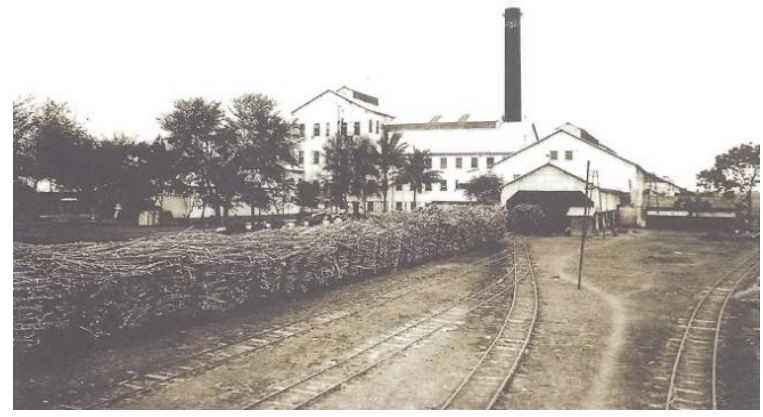

Fig. 1. Basic land use and division - Zongye sugar refinery.

\section{B. Office Area}

The office and administrative area acted as a buffer between the factory and residential areas and can be seen as the boundary between the two. In addition to the space required for offices for each department, this area also included a restaurant and reception area (for use when the Japanese governor-general in Taiwan made inspections). The administrative system for sugar factories under Japanese rule was divided into supervisors and workers. Supervisors were technical workers sent from Japan to oversee factory work, and workers were local Taiwanese people hired to do low-level labour. The refinery chief had his own separate office located in the centre of the entire grounds. In the case of the Kio-A-Thau sugar plant, during the beginning of its operations, there was a tropical colonial style office building (the business offices built in 1901 for Taiwan Sugar Co. Ltd.) and a club, which are important historical buildings from the Japanese occupation of Taiwan (see Fig. 2). The office buildings were among the first reinforced concrete brick buildings in Taiwan; their structures incorporated wooden architecture (roof trussing and foundation piling), brick masonry (facade), and reinforced concrete (vestibule pillars) and were important undertakings in Taiwan's civil engineering history. As the building with the most historic value, the style was basically modelled after the Dutch buildings in Southeast Asia in the tropical colonial style. The Kio-A-Thau sugar refinery is considered the beginning of this style of architecture in Taiwan. The raw materials storage area must be built closest to the sugar cane fields; therefore, the completed sugar storage area was also built close to outgoing transportation.

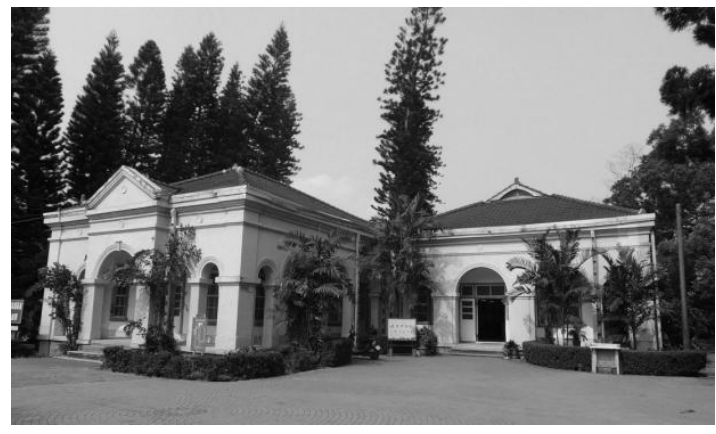

Fig. 2. The original club in the KIO-A-THAU sugar refinery.

\section{Residential Area}

Naturally, the Japanese people who were required to move to Taiwan for work brought with them their architectural culture and deep-rooted traditional customs. The addition of these Japanese influences made spatial divisions more diverse. Residential areas included parks and green spaces to improve the quality of life, shrines for spiritual life, ethnic public bathhouses, schools, stores, libraries, and hair salons for workers, as well as communal activity areas, air defence facilities, fire prevention facilities, and other safety systems to give sugar factory communities a more distinct and strict sense of organization compared to other communities and to fulfil all worker needs. In general, Japanese supervisor residential areas were on the factory grounds protected by the management system, whereas the Taiwanese worker residential areas were more closely related to nearby villages.

The housing system within the residential area was a scaled system structured around administrative rank. Building types were allocated according to level of rank: factory chiefs lived in separate housing, managers lived in duplexes, section heads lived in four-row houses, engineers 
lived in six-row houses, and the rest lived in eight- or ten-row houses. The areas of the housing and courtyards also varied, clearly delineating the different ranks. The majority of houses for Japanese workers had smaller front and back courtyards and were near public bath houses, public facilities, and communal halls. The roofing was generally decided by the sugar company's system; earlier buildings and lower rank housing had little embellishments, and roofing became more complex as time progressed. The entrances used several elements to reflect the ranking system: the simplest was a single door overhang, next was an overhang with pillars, and the most complex was the entrance to the factory chief's housing, which included an overhang with pillars and stone steps. Due to these markers, the residents' ranks were obvious from first glance. There was also a typical place of worship, i.e. a shrine, within the residential area. Most company shrines worshiped the gods the local people believed in and the Shinto gods, while those of some Japanese sugar companies, for example, Taiwan Sugar Co. Ltd.'s Kio-Thau and Yongkang sugar refineries, only worshiped Japanese Shinto gods. Aside from shrines, residential areas also included guest houses, clubs, hair salons, and air defence bunkers (see Fig. 3).

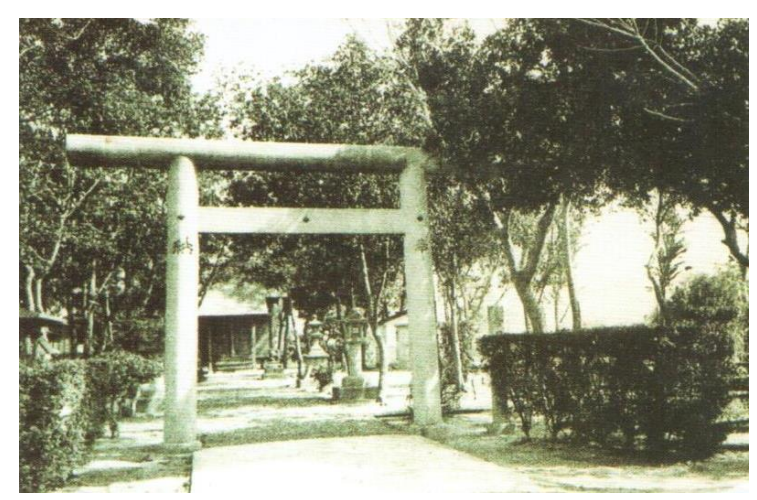

Fig. 3. Shrine in the Dalin sugar refinery.

\section{Taiwan Sugar Railways}

The early transportation network at Kio-A-Thau sugar plant was mostly comprised of rudimentary pathways. Not until 1907, after permission was granted by the governor-general's office, was Taiwan's first railway for the sugar industry constructed, marking the beginning of Taiwan's sugar railways. Taiwan's sugar railways were typically seen in fields and small towns, and it was common to see train cars full of sugar cane, especially during the time of sugar production [7]. At the height of Taiwan's sugar industry, 3,000 kilometres of sugar railways interlaced the boundless sugar cane fields across Taiwan. Though car models varied, all of the railways had a 30-inch track gauge, and the tracks connected 21 different sugar rail lines [8]. The pictures below show the close spatial relationships between the sugar railways and the sugar refineries.

\section{FURTHER DEVELOPMENT AND REUSE OF SUGAR REFINERY SPACE}

After 1985, Taiwan's sugar production decreased to 600,000 tons that were only for domestic consumption, with many refineries closing and the industry itself becoming a declining one maintained by the marketing of by-products and the selling of land. In recent years, the economic role and position of the industry has dropped even further. The special history behind sugar gave importance to the fields, which produced mixed feelings about the factory space. As the purpose of establishing the sugar factories during the Japanese occupation was mainly for producing sugar and because the political power at the time was a foreign colonial government with strong economic power, the spaces surrounding the sugar refineries built at that time have three types of influences:

1) Functional influence: the structures and distribution of the large factory spaces were mainly decided by the suitability of raw sugar cane and the concentration of sugar cane in each area; higher output value meant a denser factory. In addition, the functionality of sugar production mainly influenced the factory area which made the sugar; the fluidity and economy of the entire sugar production system were also the foundation of the factory area space.

2) Historical and cultural influence: original structures already existed when new sugar refineries were first being built. The residents within the sugar factories from the Japanese occupation accumulated basic Japanese customs to feel more at home. More importantly, the spatial relationships within the factory premises reflected each sugar company's institutional characteristics.

3) Environmental influence: the spatial structures within the sugar factory were developed from the original structure, and factory space allocation was adjusted based on the external environment. These external environmental influences included the winds, terrain, and waterways in the natural environment [9].

Investigating the re-use of sugar refineries must begin with the areas allocated in urban planning and must include evaluations of city design and building design as well. When the sugar refinery and its neighbouring or attached facilities have a complete and rich colonial history, laws pertaining to the conservation of cultural assets must give special recognition to the industrial legacy.

As Judith A.'s research on industrial culture pointed out many of the regeneration projects of industrial sites have tended to ignore industrial culture and its industrial past, often seen as something best forgotten. This has happened to the creative cultural sites in Taiwan, preceded by the aim to form facilities for creative industry, without evaluation of the future new uses in order to meet the alliance of economic renewal with conservation which may foster adaptive re-use of redundant buildings [10]. As such, factories which have already shut down or will soon disappear can serve as industrial remnants of colonial history which can help to tell the history of Taiwan.

\section{CONCLUSION}

This study summarized the spatial relationships between sugar refineries, factory areas, and surrounding spaces, and determined that factory areas were mostly planned in a geometric structure and that positioning was adjusted based on the actual terrain. The industrial communities of the new sugar factories built during the Japanese occupation of 
Taiwan became complete and organized collective villages. These areas were built to provide a complete and safe environment for immigrants. Under the influence of the Japanese governor-general's administrative planning in Taiwan, the sugar industry helped Japanese citizens to immigrate to Taiwan, and the attached facilities gave these immigrants proper care. The history of the sugar industry represents Taiwan's colonial history, one filled with tears and blood, but on the other hand, the sugar industry comprised $90 \%$ of Taiwan's foreign exchanges in the 1960s, and without the industrialization brought about by the sugar industry, there would be no high tech industry in Taiwan today.

The emergence of the sugar industry is closely related to the national characteristics, financial groups, and local influences involved. The symbol of sugar industry culture is the symbol of politics. However, the situation that the Taiwan Sugar Corporation faces now is large tracts of land and many obsolete factories. Their future redevelopment or re-use begins with investigating the characteristics of the factory spaces and spatial structures, including measuring the value of the industrial heritage in different areas, to clarify whether the next step can create a sustainable operational model for the neighbouring communities that comply with local needs and values. The convenience of the factories and their transportation, along with their rich cultural landscapes and complete ecological environments, can also be considered in plans to provide advantageous development and re-use. The remaining sugar factories and surrounding lands were shaped by their various owners and overturned by waves of human activity. The Taiwan Sugar Corporation is left with large tracts of land being eyed covetously by many developers, yet the company must maintain the cultural value of these lands and create a balance with commercial benefits, gradually establishing the important value of the sugar industry in Taiwan.

This research has analysed the ways in which the sugar factories are sites that contribute to the production of the colonial past. The challenges faced concern the utilisation and reuse of these sites that were established for economic, social, geographical reasons. The research will also introduce the connection which should involve the cooperation with the communities in the factories location and the development of the future use. Three of these factories have been instituted as Creative Cultural Parks and one is used for art and cultural events. These factories are focused on new use and the properties can efficiently contribute extra space for various functions. However consideration should be taken of their historical significance stemming from their industrial and colonial pasts, and management plans initiated that recognise their historical uniqueness. Therefore, no matter what their future function will be they will respect the cultural heritage which is a witness to history.

\section{REFERENCES}

[1] Z. Y. Tu, Taiwan Under Japanese Imperialism, M. J. Li trans., Renjian, 1992.

[2] S. Association, "Taiwan sugar culture association," Modern History of Japan's Sugar Industry, 2007, vol. 1, pp. 269-292.

[3] J. L Zhou and Y. H. Xu, Nanying Sugar Factories, Tainan: Tainan County Government, 2000

[4] Taiwan Sugar Corporation, Taiwan Sugar: 50 Years, 1997.

[5] X. X. Zeng and H. S. Guo, "A study on the factors for the conservation of the landscape of sugar refineries in Taiwan: the case of Kio-A-Thau sugar refinery," Journal of Environment and Art, vol. 7, pp.17-36, June 2009.

[6] P. C. Cheng, "The study of the space of new sugar factory in Taiwan during the Japanese occupied period," M.A. thesis, Dept. of Architecture, National Cheng Kung Univ., Tainan, Taiwan, 2000.

[7] Y. Q. Yang, 100 Years of Sugar in Taiwan, 2001.

[8] M. Y. Chen, "The origins of the Taiwan sugar railways," An Illustrated Collection of Taiwan's Sugar Railways, Taiwan Wuzhi Commemorative Sugar Association, 2004.

[9] Y. F. Chen, "An Inquiry into sugar industry factory space construction in Taiwan," M.A. thesis, Dept. of Architecture, Tunghai Univ., Taichung, Taiwan, 1996.

[10] J. Alfrey, The Industrial Heritage: Managing Resources and Uses, Routledge, 1992.

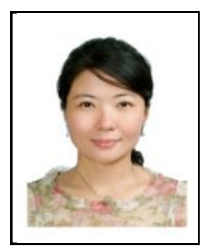

Hui-Wen Lin was born in Taipei, Taiwan in 1974. She earned her Ph.D. in architecture in 2008 at National Cheng Kung University in Taiwan, she earned her M.A. in 1999 and B.A. (hons) in 1997, both in interior design, from Manchester Metropolitan University in the UK.

She joined the National Cheng Kung University Faculty in 2012 as an assistant professor in the Institute of Creative Industries. Prior to that she was a faculty member at the Kun Shan University of Technology at the Department of Spatial Design in 1999-2012. She was awarded the best teaching in 2011. She was invited to be a visiting scholar at the Centre of Humanity and Social Science in the National Science Council in Taiwan July, 2013 as well as a visiting scholar in Fudan University in China April, 2013. Her experience and expertise has enabled her to contribute over 30 research papers to conferences and journals. These have mainly focused on issues relating to the sites and places that are associated with significant events, for their social and cultural meanings. Her doctoral degree dissertation was funded and awarded by Cultural Bureau in 2008. Her research outcomes include the book chapter published in Patrimoine en devenir ; penser et pratiquer l'esprit du lieu in Montréal 2010 under the title of "Reveal spirit of place by war monumentality and its monumental meanings: purpose of monument erection in Kinmen Island, Taiwan", and the paper published in the Journal of Conservation of Cultural Heritage by Cultural Bureau in Taipei 2010 under the title of "The 'memorised' and 'forgotten' difficult past of holocaust: rethinking the authentic site to traumatic cultural heritage".

Dr. Lin has been a member of the international council on monuments and sites (ICOMOS) since 2013 and the society of architectural historian of Taiwan since 2008, and was elected as director in 2010. She has also been elected as director of the foundation of historic city conservation and regeneration in 2012. She has been a member of the Architectural Institute of Taiwan since 2005 . 